\title{
The Dead Sea hydrography from 1992 to 2000
}

\author{
I. Gertman*, A. Hecht \\ Israel Oceanographic and Limnological Research, National Institute of Oceanography, P.O. Box 8030, Haifa, Israel
}

Received 20 September 2001; accepted 11 January 2002

\begin{abstract}
The modern hydrological regime of the Dead Sea is strongly affected by anthropogenic activity. The natural fresh water budget has changed mainly due to the drastic reduction of runoff. Since 1977, the surface level of the Dead Sea has been lowered by an average rate of about $60 \mathrm{~cm} /$ year and for the period from 1998 to 2000, the lowering rate has reached about 100 $\mathrm{cm} /$ year. As a result of the runoff reduction, the upper layer salinity of the Dead Sea has increased and the gravitational stability of the water body was diminished. Eventually, during the winter of 1978-1979, the lake waters overturned, bringing to an end the long-term stable meromictic ${ }^{1}$ hydrological regime. The lake entered a new phase in which its hydrological regime switches between holomictic and meromictic regimes, depending on the size of the runoff into the lake (i.e. the amount of precipitation in the lake's watershed). The first holomictic period, 1979-1980, lasted for 2 months only. It was succeeded by a 4-year meromictic period (1980-1983). The second holomictic period lasted for 9 years (1983-1991). The rainy winter of 19911992 resulted in an almost 2-m sea level rise. The upper layer with a relatively low salinity was restored and a new meromictic period persisted for 4 years, until winter 1995-1996. During the last meromictic period, the hydrological regime of the Dead Sea was characterized by following long-term trends: the depth of the summer thermocline increased from $12-15$ to $25-30 \mathrm{~m}$; the quasi-salinity of the upper layer, initially of about $164 \mathrm{~kg} / \mathrm{m}^{3}$, increased rapidly at a rate of about $16-18 \mathrm{~kg} / \mathrm{m}^{3} / \mathrm{year}$; the quasi-salinity of the deep water, initially of about $235 \mathrm{~kg} / \mathrm{m}^{3}$, decreased slowly at a rate of about $0.08-0.10 \mathrm{~kg} / \mathrm{m}^{3} /$ year (for the sake of comparison, a quasi salinity of $235 \mathrm{~kg} / \mathrm{m}^{3}$ is the equivalent of $280 \%$ "usual" salinity); and the winter minimal temperature of the upper layer, initially of about $16{ }^{\circ} \mathrm{C}$, increased rapidly at a rate of about $2{ }^{\circ} \mathrm{C} /$ year. In November 1995 , the latest meromictic period of the Dead Sea came to an end. During the present holomictic period, 1996-2000, the hydrological regime of the Dead Sea is also characterized by long-term trends: the quasi-salinity of the entire Dead Sea increased at a rate of about $0.5 \mathrm{~kg} / \mathrm{m}^{3} /$ year, with practically no decrease during the winters; the temperature of the deep water mass increased with a rate of about $0.25{ }^{\circ} \mathrm{C} /$ year; and the period of vertical convection of the entire water column, initially about 3 months, increased at a rate of about 1 week/year. Moreover, we observed that the temperature and salinity of the bottom layer in the deepest part of the Dead Sea raised by about $0.5-0.6{ }^{\circ} \mathrm{C}$ and $0.15-0.25 \mathrm{~kg} / \mathrm{m}^{3}$ during each holomictic summer. (C) 2002 Elsevier Science B.V. All rights reserved.
\end{abstract}

Keywords: Dead Sea; Anthropogenic effects; Thermohaline structure; Vertical stability of water column

\footnotetext{
* Corresponding author. Fax: +972-4-8511911.

E-mail address: isaac@ocean.org.il (I. Gertman).

1 Meromictic lake - a lake that undergoes incomplete mixing of its waters during periods of circulation. Holomictic lake-a lake that undergoes a complete mixing of its waters during periods of circulation or overturn.
}

\section{Introduction}

The Dead Sea is a large and deep terminal lake, situated in the lowest section of the Jordan Rift Valley between Israel and Jordan (Fig. 1). As a terminal lake, the level of the Dead Sea is determined by the balance 


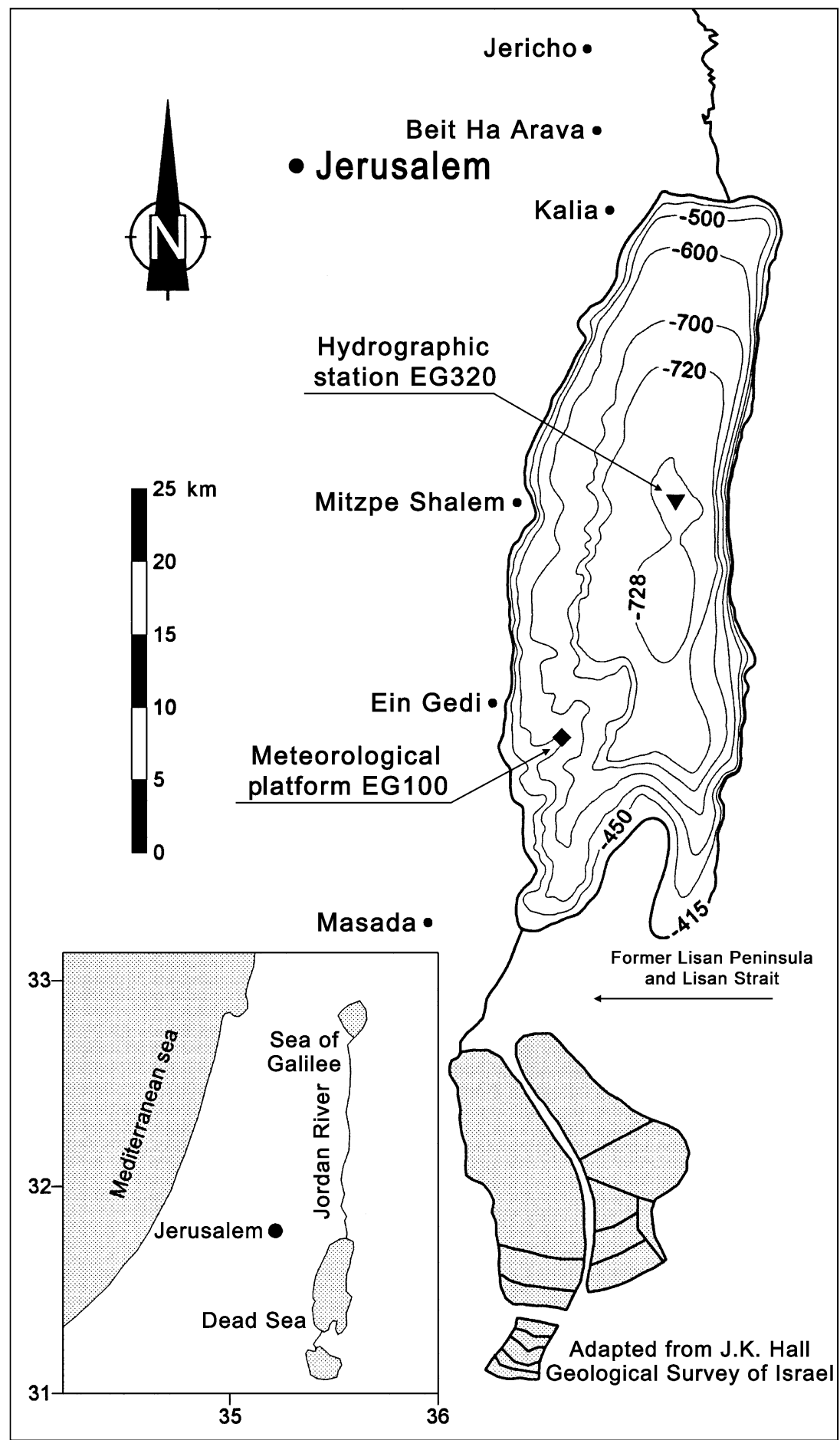

Fig. 1. A map of the Dead Sea showing the present (year 2001) shoreline at $-415 \mathrm{~m}$, and the location of the sampling stations. 
between evaporation, rain and runoff (the last including the inflow of subsurface springs). Historical records (Klein, 1960, 1981, 1982, 1990) indicate that throughout its existence, the water level of the Dead Sea oscillated significantly. However, since the early 1960 s, the countries controlling the fresh watershed of the Dead Sea (i.e. Israel, Syria and Jordan) began to use these waters intensively (e.g. Salameh and Khawaj, 1984). As a result, the inflow of fresh waters into the Dead Sea has diminished significantly and the evaporation from the lake exceeded rain and runoff into it. Moreover, Israel and Jordan are using the Dead Sea waters for the production of minerals, which also contributes to the depletion of these waters. Thus, from a level of $-397 \mathrm{~m}$ (i.e. $397 \mathrm{~m}$ below mean sea level) in 1960, the surface of the Dead Sea has dropped almost continuously (Steinhorn and Assaf, 1980; Anati and Shasha, 1989) and at the beginning of 1978 (Steinhorn, 1981), it went below $-399.6 \mathrm{~m}$, the level of the sill of the Lynch Straits (Fig. 1). ${ }^{2}$ Until that time, the morphology of the Dead Sea consisted of a large and deep northern basin and a smaller and much shallower southern basin, the two communicating via the Lynch Straits (e.g. Neev and Emery, 1967). Following the recession of the water level, the entire southern basin would have dried up. The erection of dikes transformed the area of the southern basin into evaporation ponds for the production of minerals. The water in those ponds is pumped in from the northern basin of the Dead Sea. Moreover, with the recession of the water level below the level of the Lynch Straits (in 1978), the length of the Dead Sea decreased from 80 to about $50 \mathrm{~km}$, its maximum depth has diminished to $328 \mathrm{~m}$, its surface area has diminished to $815 \mathrm{~km}^{2}$ and its volume has diminished to $146 \mathrm{~km}^{3}$ (Neev and Hall, 1979). The sea surface level of the Dead Sea is still dropping and in 2001 has reached $-414 \mathrm{~m}$ (Fig. 2), while its maximum depth has been reduced to 316 m. As shown by Yechieli et al. (1998) and by Krumgalz et al. (2000), due to thermodynamic constrains, the Dead Sea evaporation will reach a balance,

\footnotetext{
${ }^{2}$ Note that one must exercise some care when discussing the published levels of the Dead Sea, since there is a 2.38-m difference between the measurements provided by the Dead Sea Works and those given by the Hydrological Survey of Israel (see Steinhorn, 1981, p. 4). In the present paper, the water level of the surface of the Dead Sea is presented according to the Hydrological Survey of Israel.
}

which will prevent the further reduction of its sea level. This is expected to occur in about 500 years when the Dead Sea level will drop to about $-550 \mathrm{~m}$ below mean sea level.

The chemical composition of the waters of the Dead Sea is relatively rich in calcium, magnesium, potassium and bromine, and relatively poor in sodium, sulfate and carbonate, thus significantly different from those of usual seawater (e.g. Neev and Emery, 1967). Strictly speaking, in view of the peculiar chemical composition of its waters, the accepted definition of "salinity" does not apply to the waters of this lake and it has been replaced by an equivalent salinity based on pycnometry (Anati, 1999) and referred to as "quasi-salinity". Thus, quasi-salinity is defined as the Dead Sea water density anomaly from $1000 \mathrm{~kg} / \mathrm{m}^{3}$ at an arbitrary reference temperature of $25{ }^{\circ} \mathrm{C}$.

The vertical stability of a lake is determined by the temperature and the salinity of its waters. In the Dead Sea, the fresh water influx mixed into the upper layer and reduced its salinity to such a degree that the seasonal cooling did not increase its density to more than that of the layer beneath it (e.g. Steinhorn and Assaf, 1980). Thus, the Dead Sea was defined as meromictic, as opposed to the more common cases of holomictic lakes that go through a mixing or overturn stage once a year (e.g. Steinhorn and Gat, 1983).

The terms "meromictic" and "holomictic" were coined by Hutchinson (1957). A holomictic period is characterized by stable stratification during the summer season, and overturn during the winter season. On the other hand, a meromictic period is characterized by a stable stratification throughout the year, i.e. no overturn during the winter. The Dead Sea has been a meromictic lake for several centuries. However, due to the diminishing fresh water runoff into the lake, the salinity of the upper layer increased and eventually, during the winter of 1978-1979, the lake waters overturned and the lake entered a short holomictic stage which lasted for 2 months only (Steinhorn and Gat, 1983; Steinhorn, 1985; Anati et al., 1987, see also Fig. 2). With that event, the Dead Sea entered a new phase in which it switches from one regime to the other.

In view of the importance of the Dead Sea, both as a unique natural phenomenon and as source of revenue from tourism and from the exploitation of the 


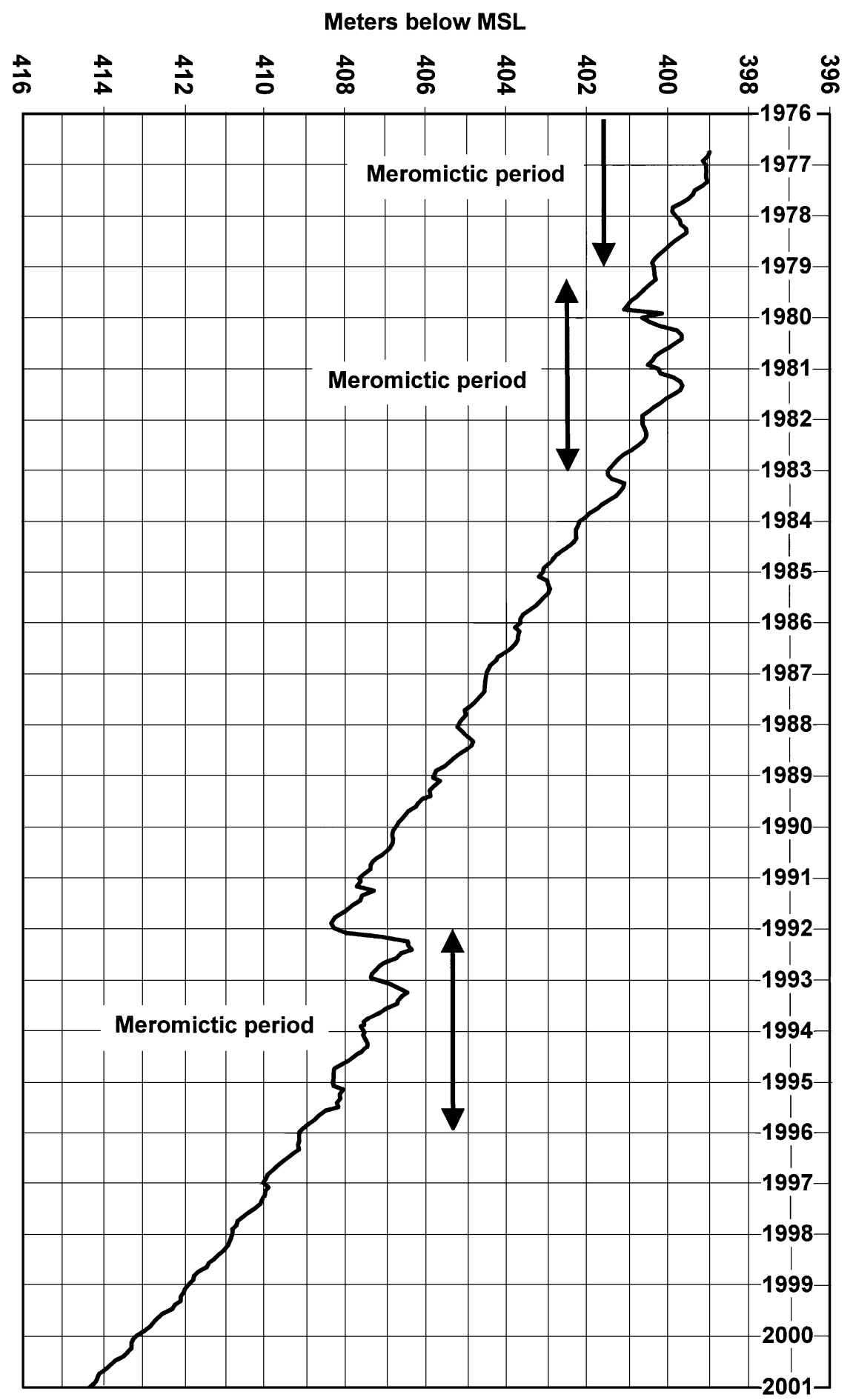

Fig. 2. Changes in the Dead Sea water level and the meromictic periods (holomictic periods between the meromictic periods). 


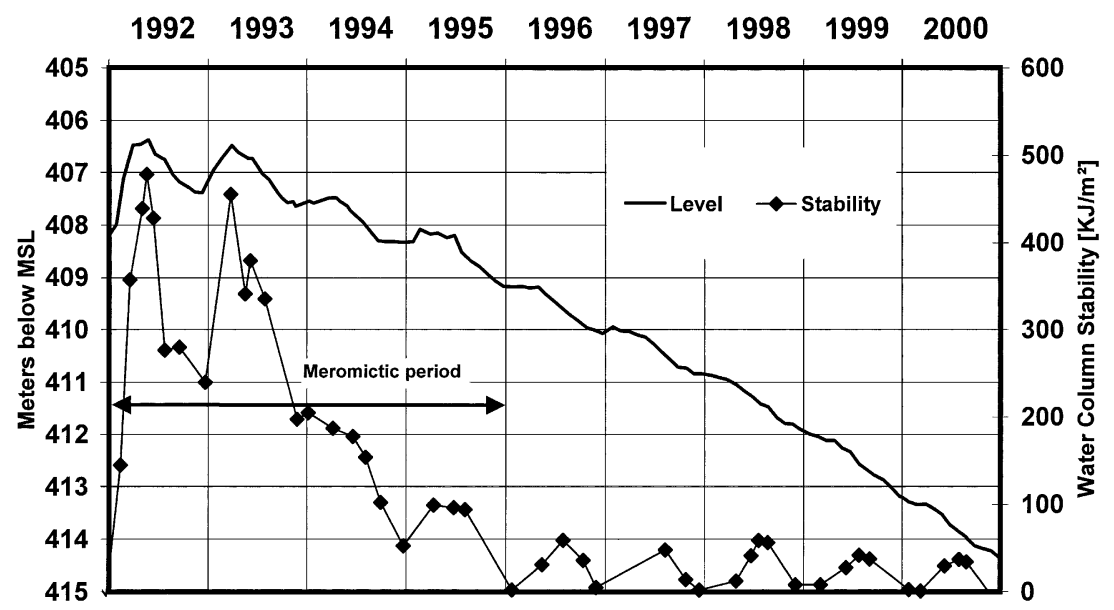

Fig. 3. Changes in the Dead Sea water level and the water column stability.

dissolved minerals in its waters, systematic monitoring of the Dead Sea hydrography began in 1977. Its findings and main results and conclusions were published throughout the years in the scientific literature (see Arad et al., 1998; Anati et al., 1995; Anati, 1997). These cover, fairly reliably, the years 1977-1991, but are less detailed concerning the post-1991 period. The following is a necessary update covering the years from 1992 to 2000 .

The analysis of seasonal and long-term variability of the Dead Sea hydrography in the present investigation is based on two long-term databases. The first one consists of standard hydrographic casts at the deepest point of the Dead Sea (EG320), situated 15 $\mathrm{km}$ northeast off En Gedi (Fig. 1). These measurements were carried out at about two monthly intervals by the Hebrew University in Jerusalem (Anati, 1997) and since 1988, by the Israel National Institute of Oceanography. The second database consists of upper layer quasi-continuous water temperature observations carried out by the Israel National Institute of Oceanography, since 1992, from the Dead Sea meteorological platform (at EG100) situated $4 \mathrm{~km}$ southeast off En Gedi (Hecht et al., 1992). The temperatures were measured by a thermistor chain at 20-min intervals. ${ }^{3}$

\footnotetext{
3 Additional details can be found at http://www.marine.ocean. org.il/DS_website/DS_Main.htm.
}

\section{Basic hydrological features}

Since 1977, the surface level of the Dead Sea has been dropping at an average rate of about $60 \mathrm{~cm} /$ year (Fig. 2). In the time sequence of this surface level trend, there are two conspicuous events in the opposite sense: the level rises of winter 1980 and 1992, both following large amounts of fresh water inflows from floods and from river runoff. Apart from these two special events, the Dead Sea surface level has been dropping at a faster rate, namely $80 \mathrm{~cm} /$ year, with variability of less than $2 \%$. The large level rise of 1992, almost $2 \mathrm{~m}$, brought about a meromictic period which persisted for 4 years, the same duration as the previous meromictic period which lasted from 1980 to 1983 (Anati et al., 1987). The transition between the holomictic and the meromictic regimes can be monitored via the analysis of the vertical stability of the water layers.

Traditionally, the vertical integrated stability per unit area of a lake can be estimated from:

$W=\frac{g}{A(0)} \int_{0}^{h}(\rho(z)-\bar{\rho}) A(z) z \mathrm{~d} z$

where $W$ is the energy required to mix the water column, $A(z)$ is the horizontal area of the lake at depth $z, \rho(z)$ is the observed vertical profile of potential density, $\bar{\rho}$ is the average of $\rho(z)$ and $h$ is the maximal depth of the lake (Anati, 1997). The required energy 
sources can be either buoyancy flux, or mechanical energy (e.g. winds, waves and currents) or both.

The stability changes in the Dead Sea since 1992 illustrate well the main difference between a meromictic period, during which the stability never vanished, and a holomictic period, during which, at least once a year, the entire water column is mixed and its stability is reduced to zero (Fig. 3). In March 1992, the Dead Sea was found to be stably stratified (Fig. 3). Therefore, the Dead Sea was already meromictic for some time. The onset of this meromictic period is estimated to have occurred around mid-January 1992.

\section{The upper layer}

The sharp increase in the total stability of the Dead Sea in 1992-1993 was induced by the large inflow of fresh water due to the extremely rainy winter, 19911992 (Beyth et al., 1993). The thickness of the newly formed upper layer with relatively low salinity was not more than $20 \mathrm{~m}$ (see Fig. 4 of Beyth et al., 1993), but its presence changed the hydrological regime of the Dead Sea completely for the following 4 years.

During the summer of 1991, the quasi-salinity of the surface layer of the Dead Sea reached a maximum of about $236 \mathrm{~kg} / \mathrm{m}^{3}$. During the following winter, the surface layer quasi-salinity dropped to $164 \mathrm{~kg} / \mathrm{m}^{3}$ (Beyth et al., 1993). The presence of an upper layer with a lower salinity than that of the water beneath it, produced a very stable interface (i.e. a "virtual bottom") and thus, impeded vertical mixing between the layers. During the summer of 1992, the depth of the seasonal thermocline was about $10 \mathrm{~m}$ (Fig. 4). After the winter of 1991-1992, evaporation exceeded precipitation and runoff. Therefore, the positive vertical gradient of salinity in the upper layer was worn out. The depth of the summer thermocline increased during the first 3 years: during the summer of 1993 it reached $12-15 \mathrm{~m}$, during the summer of 1994 it reached 18-20 m and during the summer of 1995 it reached the relatively stable position of about $25-30$ m (Fig. 4).

During the winter of 1992-1993, the upper layer water temperature dropped to $16-17{ }^{\circ} \mathrm{C}$, which was cooler than the water beneath it by about $5-6{ }^{\circ} \mathrm{C}$. Nevertheless, during this winter, the convection ceased at a depth of about $15-20 \mathrm{~m}$ due to a positive gradient of salinity in the upper layer. Similar overcooling of the upper layer, relative to the deep water, was also observed during the winters of 1993-1994 and 19941995. This phenomenon is typical of meromictic seas (e.g. the Black Sea-Gertman and Golubeva, 1988) where winter cooling affects only a relatively shallow upper layer located above a positive halocline.

From 1992 to 1999, the monthly averaged February temperatures of the Dead Sea upper 1-m layer show a significant positive trend from 16.5 to $22.9{ }^{\circ} \mathrm{C}$ (Fig. 4). For the same period, the monthly averaged August temperature of the same layer fluctuated near a mean value of $33.7{ }^{\circ} \mathrm{C}$ with a standard deviation 0.5 ${ }^{\circ} \mathrm{C}$. A one-dimensional integral model in isopycnal coordinates, including the upper mixed layer (Gertman et al., in press), simulating the long-term evolution (1992-2000) of the Dead Sea structure, produced similar temperature changes. The surface forcing for the simulations was calculated from the IOLR meteoplatform measurements. The simulation does not reveal any significant trend in the sea surface heat fluxes, either during the summers or during the winters of the investigated period. On the other hand, during the winters following the rainy winter of $1991-1992$, the intensity of the halocline diminished, the depth of the mixed layer increased from 10-20 m to the depth of the entire water column, and the heat capacity of the mixed layer increased. Therefore, the same winter heat flux did not cool the layer to the same degree, thus, the positive trend in the mixed layer winter temperatures.

The depth of the summer upper mixed layer also increased during the meromictic regime degradation but only from about $12 \mathrm{~m}$ during the summer of 1992, to about $25 \mathrm{~m}$ during the summer of 1996 (Fig. 4). Therefore, the August temperature of the meromictic upper layer showed no significant long-term changes.

At the same time, the salinity of the meromictic upper layer increased dramatically and in the summer of 1995, it overshot the salinity of the deep water. During the autumn of 1995 , convection mixed the entire volume of the sea. Thus, in November 1995, the latest meromictic period of the Dead Sea came to an end.

Since the onset of the new holomictic period, longterm tendencies in the upper layer parameters became less evident. Every holomictic winter convection completely destroys stratification. The increase of 


\section{ర}

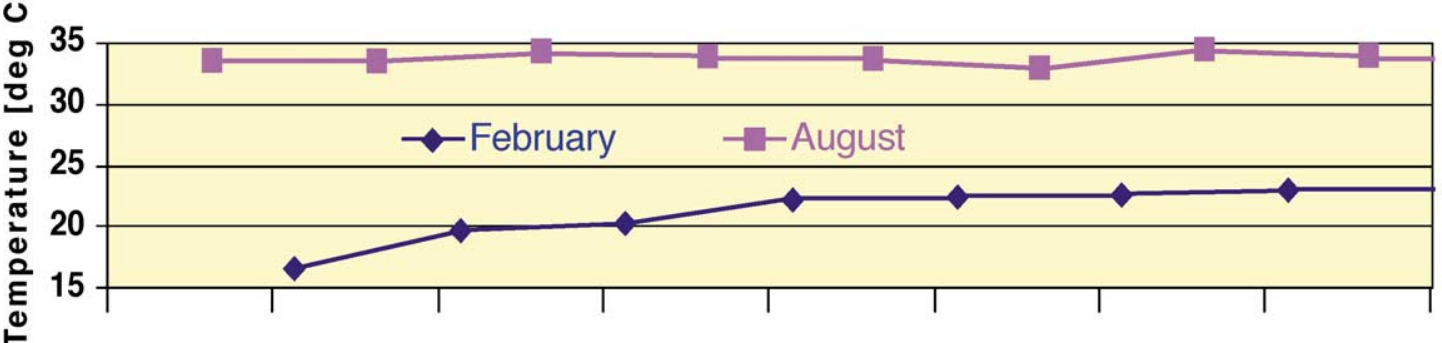

$\begin{array}{llllllll}1992 & 1993 & 1994 & 1995 & 1996 & 1997 & 1998 & 1999\end{array}$

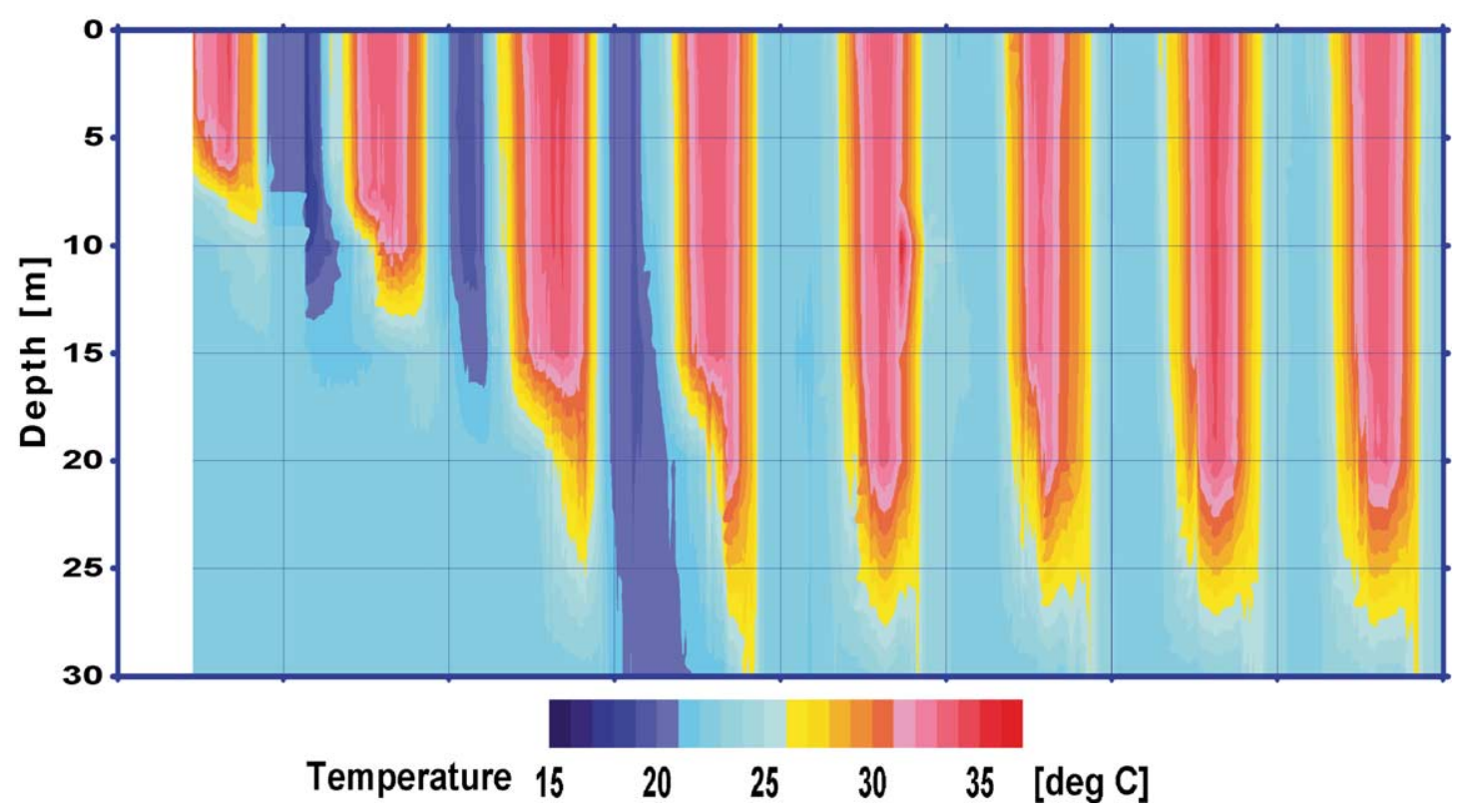

Fig. 4. Long-term changes of water temperature $\left({ }^{\circ} \mathrm{C}\right)$ measured by thermistor chain from the Dead Sea meteorological platform. Upper panel presents monthly averaged surface layer temperature. Lower panel—vertical distribution of temperature averaged every 5 days.

the summer salt concentration, attributed to the fresh water budget deficit, is now not limited mainly to the upper layer volume, but it is rather distributed throughout the entire Dead Sea volume.

Seasonal changes of the holomictic upper layer will be analyzed below by using data collected during the hot and arid period between 1998 and 2000. Fig. 5 shows the evolution of water temperature and quasisalinity at $1-$ and $30-\mathrm{m}$ depth. During summer, the seasonal thermocline is constantly above the $30-\mathrm{m}$ level. During the autumn, the thermocline deepens below this level. Intensification of thermal fluctuation during this period shows the intermittent character of the mixing processes.
A stable thermocline is usually formed during the last week of March. Afterwards, evaporation induces a salt concentration increase in the layer above the thermocline. A maximum quasi-salinity $(238-240 \mathrm{~kg} /$ $\mathrm{m}^{3}$ ) is attained at the same time that the maximum upper layer temperature $\left(34-35{ }^{\circ} \mathrm{C}\right)$ is reached. The thickness of the upper layer during July-August is about 25-28 m (Fig. 6). In the second half of August, the upper layer temperature diminishes. Fig. 7 shows details of diurnal changes in the upper layer stratification for 10-20 August 1998. During the sunlight hours, insolation causes intense heating and evaporation, thus creating a diurnal thermocline and halocline at about $5 \mathrm{~m}$. At night, due to the strong destabilizing 


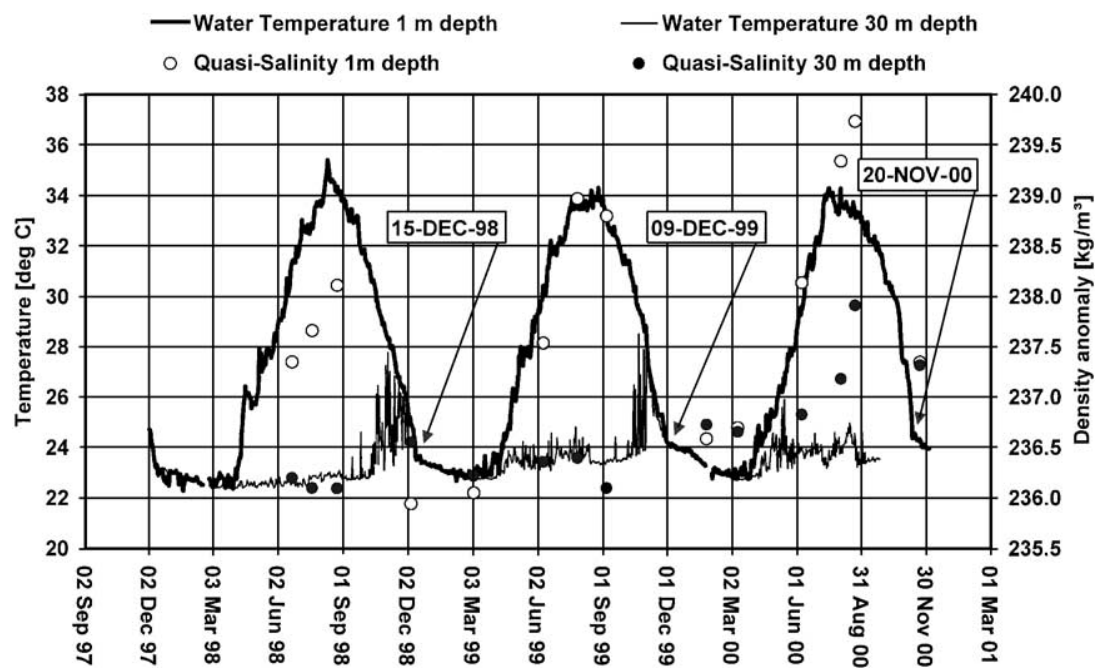

Fig. 5. Seasonal changes of temperature at the meteorological platform (station EG100) and quasi-salinity at the deepest part of the sea (station EG-320) during 1998-2000.

halocline, even slight cooling is sufficient to mix the upper layer.

The Dead Sea upper layer cooling process in the holomictic period has two phases. The first one with a rate of about $0.1{ }^{\circ} \mathrm{C} /$ day and the second one with a rate of $0.01{ }^{\circ} \mathrm{C} /$ day. During the first phase, only the upper layer above the seasonal thermocline is affected by cooling. When the thermocline goes beneath the $30-\mathrm{m}$ depth, about 30 days is necessary to entirely mix the Dead Sea volume. After this, the surface cooling rate diminishes to one-tenth of what it was. Now, negative heat flux via the sea surface leads to inten-
Temperature [deg C]

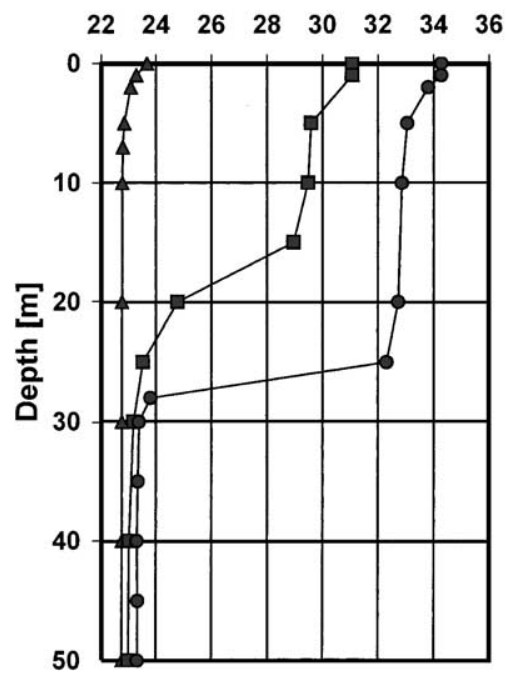

Quasi-Salinity $\left[\mathrm{kg} / \mathrm{m}^{3}\right]$

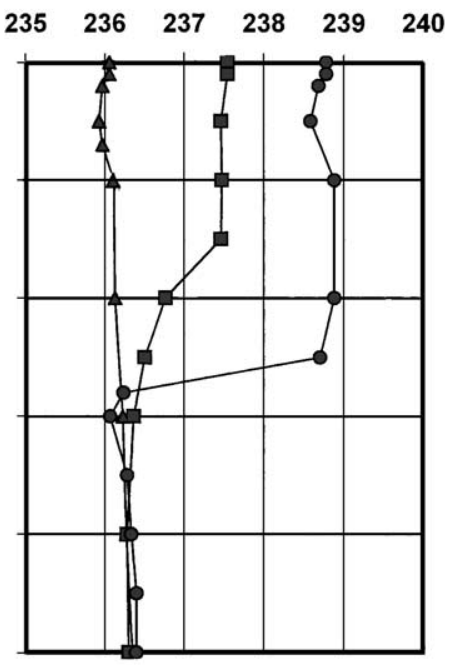

Density $\left[\mathrm{kg} / \mathrm{m}^{3}\right]$

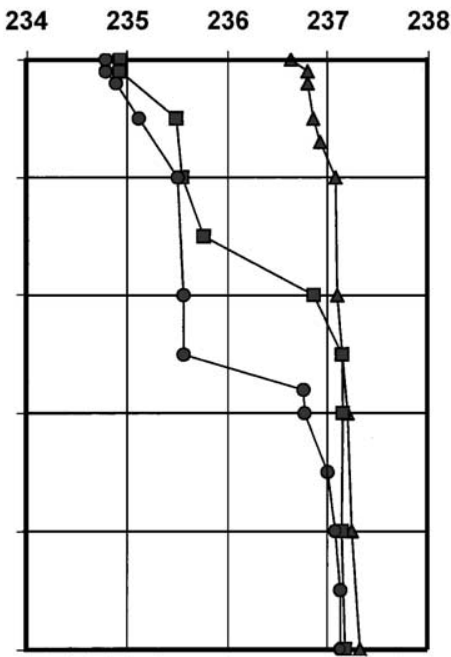

Fig. 6. Vertical distribution of temperature, quasi-salinity and density during the spring - summer period ( $\boldsymbol{\Delta}-$ March; $\boldsymbol{\square}-$ June; $\bullet-$ September) of 1999 at EG320. 


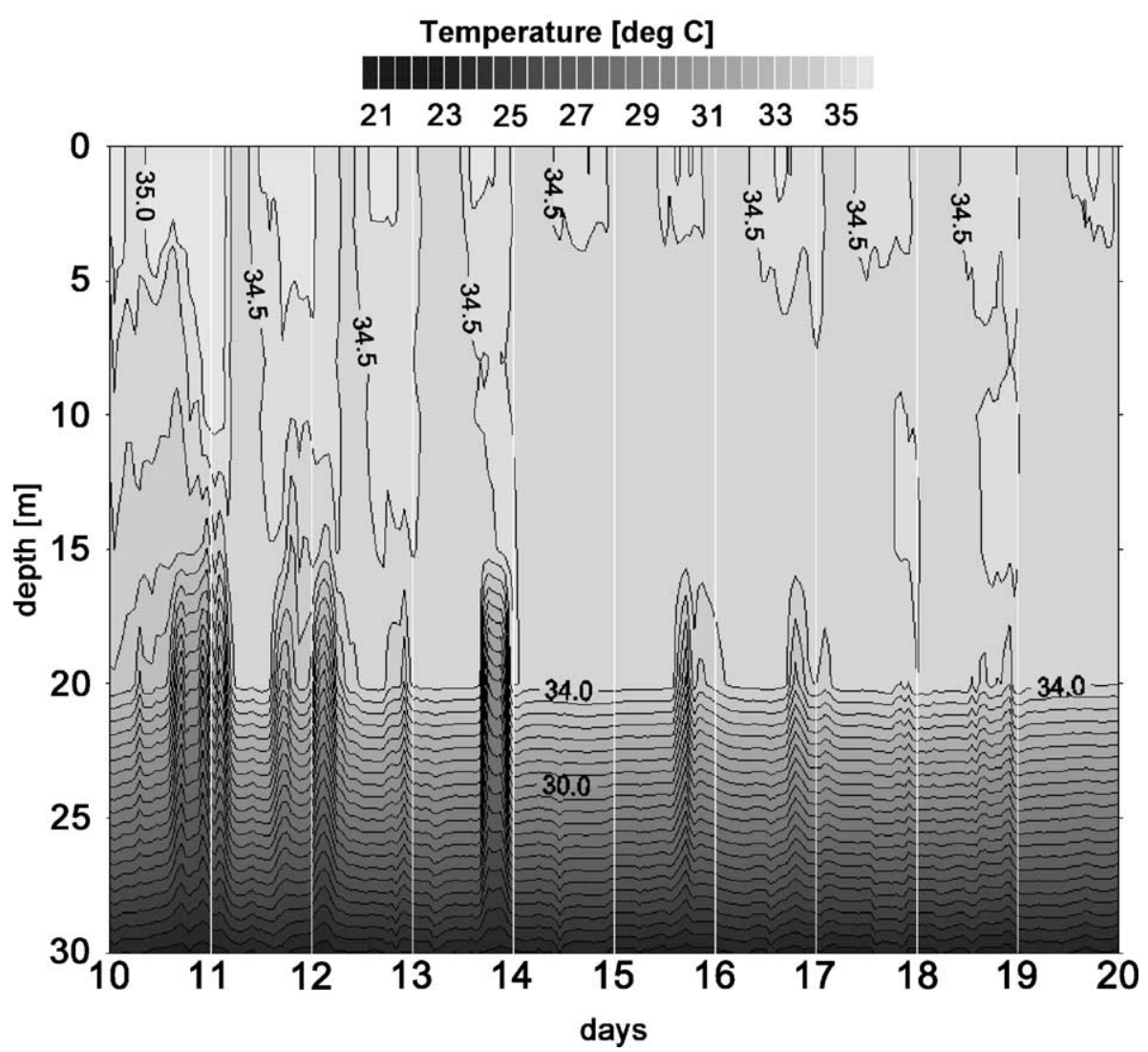

Fig. 7. Daily water temperature changes in the upper layer of the Dead Sea during 10-20 August 1998, indicating how destabilizing halocline leads to intensive mixing during night cooling.

sive convection penetrating to the bottom and serves to cool the entire Dead Sea volume. The change of the phases is related to the date of the first overturn of the Dead Sea. The date may be easily determined from the curve of the temporal changes of the Dead Sea surface temperature (Fig. 5). Thus, the first overturn in 1998 was on the 15th of December. In 1999, it occurred about 1 week earlier, and in 2000 the first overturn was observed as early as the 20th of November.

\section{The deep water}

The different signatures of meromictic and holomictic regimes will be demonstrated through the changes in the thermohaline properties of the deep water. Fig. 8 shows the evolution of the temperature and quasi-salinity in the deep water mass (depth of more than $100 \mathrm{~m}$ ) since 1992.

During the meromictic period, 1992-1995, the deep water showed no seasonality, the temperature remained almost constant $\left(22.30 \pm 0.05{ }^{\circ} \mathrm{C}\right)$. This is not surprising since at the time, the deep layer was sealed from atmospheric influences. By comparison, during the previous meromictic period of 1980-1984 (Anati et al., 1987), the deep water temperature remained within a range of $23.15 \pm 0.03{ }^{\circ} \mathrm{C}$.

On the other hand, during the holomictic periods, the seasonal variability is of about $0.5{ }^{\circ} \mathrm{C}\left(1{ }^{\circ} \mathrm{C}\right.$ peak to peak, Fig. 8), but the trend is opposite to that of the upper layers of lakes in the Northern Hemisphere. In the Dead Sea deep waters, the lowest temperatures occur after the onset of the spring-summer stratifica- 


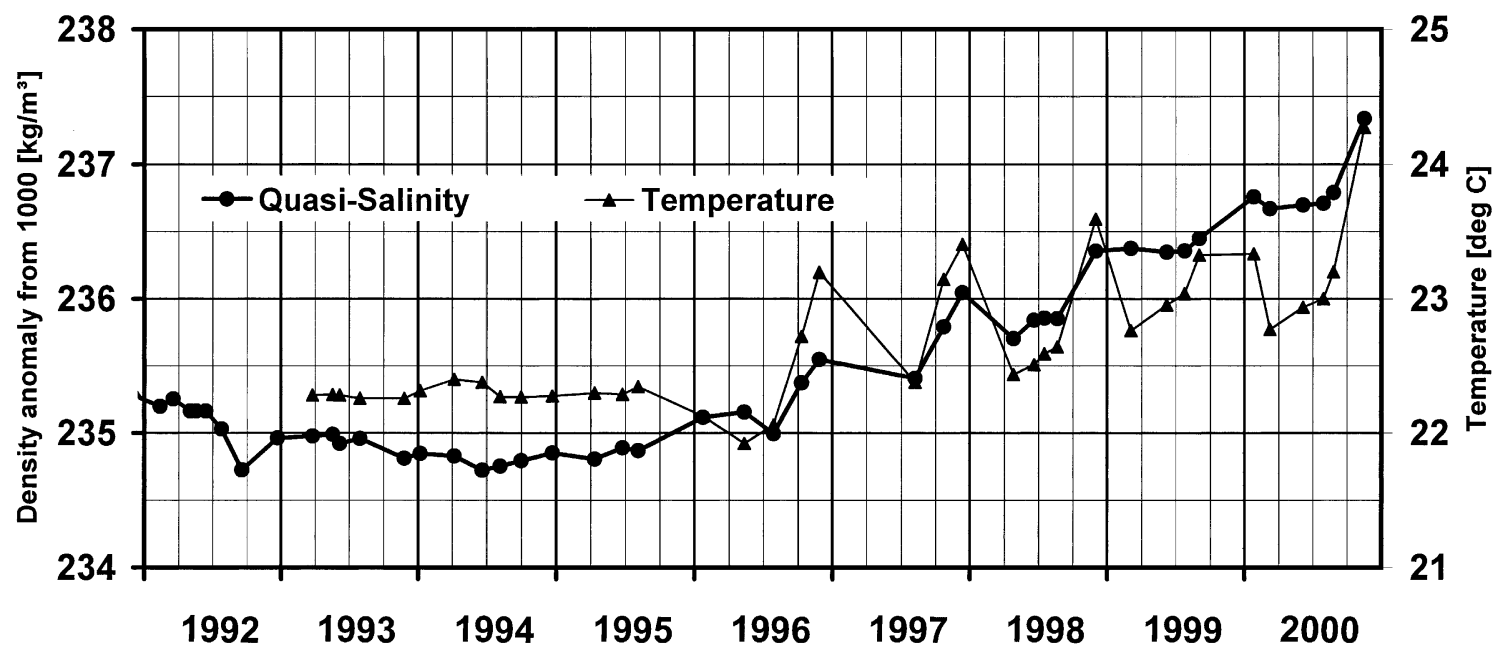

Fig. 8. Long-term changes of temperature and quasi-salinity of the Dead Sea deep water body (below $100 \mathrm{~m}$ ).

tion. Then, the deep waters begin to warm up due to vertical turbulent mixing with the upper (warmer) layer, and this ends abruptly with the yearly overturn, which occurs around December. After the overturn, the deep layers of the Dead Sea attain their highest temperatures at the beginning of the coldest season.

Throughout the meromictic period, the deep layer of the Dead Sea was sealed and thus, it could not be diluted with fresh waters. Nevertheless, a seemingly exponential decrease of salinity was observed (Fig. 8). This salinity decrease of sealed Dead Sea waters is a known phenomenon (Gavrieli, 1997), which has been attributed to halite precipitation from supersaturated brines. Just before the big 1992 floods, the Dead Sea brine was indeed supersaturated and massive salt crystal formations were documented (Gavrieli, 1997). After the winter of 1992 floods and the onset of the 1992-1995 meromictic period, the same mechanism was again operative; the deep sealed brine began approaching its steady-state saturation line "from above", thus decreasing in salt concentration. This salt relaxation process, consisting mainly of salt crystals sinking, is much slower than that found in laboratory experiments on salt crystal formation (Anati, 1993).

Moreover, during the post-1995 holomictic period, the deep water was also sealed but only seasonally. For the first 3 years (1996-1998) of the holomictic regime, during the first half of each calendar year, the salt concentration in the deep layers decreased (Fig. 8) due to winter convective mixing with the "fresher" upper layer. However, as soon as summer doublediffusive mixing with the upper (saltier) layer begins, the rate of salinity increase in the deep water is strong enough to overshoot the continuing halite loss, and the overall yearly trend is, therefore, that of increasing salinity. In 1999 as well as in 2000, a hot and dry summer was followed by a draughty winter and as a result, there was no deep water salinity decrease.

The seasonal quasi-salinity variations at the beginning of the holomictic period were approximately $0.25 \mathrm{~kg} / \mathrm{m}^{3}\left(0.5 \mathrm{~kg} / \mathrm{m}^{3}\right.$ peak to peak). It should be noted that the amplitudes of seasonal fluctuation of parameters of the deep water mass could not be estimated with sufficient accuracy because our measurements are carried out irregularly and sometimes at large time intervals. For example, we did not carry out any observations during the autumn of 1999 due to lack of an available vessel. There is no doubt that at the beginning of December 1999, the Dead Sea deep water mass reached a maxima in both temperature as well as salinity.

\section{Temperature and quasi-salinity increase in the bottom layer of the Dead Sea}

An interesting phenomenon was observed in the bottom layer of the deepest part of the Dead Sea. During the summers of 1998-2000, when mixing 
between the deep waters and the upper layer was prevented by a strong pycnocline, an increase in the quasi-salinity and the temperature in the bottom layer was observed (Fig. 9). From March to September, the increase was about $0.5-0.7{ }^{\circ} \mathrm{C}$ and $0.15-0.25 \mathrm{~kg} / \mathrm{m}^{3}$ in temperature and quasi-salinity, respectively. These values are significantly larger than the accuracy of our measurements. The thickness of the bottom layer was not more than $150 \mathrm{~m}$ and the maxima of the potential temperature and quasi-salinity were observed at the deepest level of this layer.

Details on the vertical temperature distribution in the bottom layer during the summer were observed by CTD. The distance of the CTD from the bottom was determined by an acoustic pinger, with an accuracy of $\pm 3 \mathrm{~m}$. Thus, we can state that our CTD was always within $5 \mathrm{~m}$ off the bottom. The CTD depth was calculated by dividing the measured pressure by the average water density, i.e. $1.236 \mathrm{~kg} / \mathrm{m}^{3}$. The temperature profiles of the bottom layer (Fig. 10) exhibit a

Temperature [deg C]

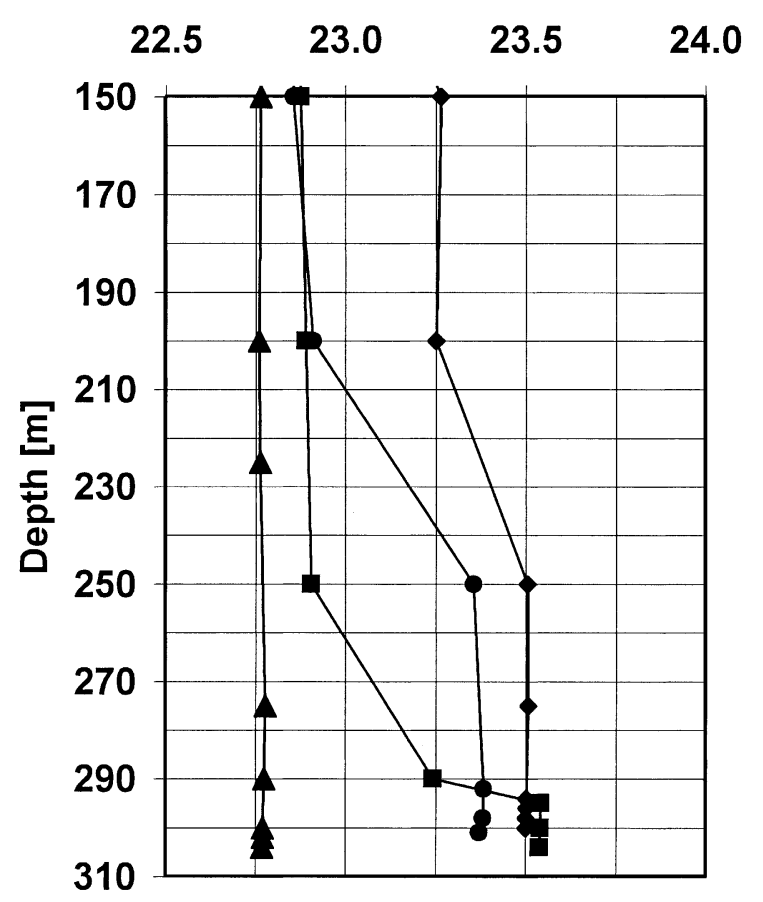

step-like feature indicating the advection of saltier, warmer and denser water into the region. The differences in the size of the steps indicate the changes in the intensity of the advection. Fig. 10 includes a temperature profile from July 2001, which, although outside the time brackets of our present paper, is a particular good illustration of the effect.

There are three possible sources for such waters. One of them is the endbrines resulting from the Dead Sea Works potash production process and discharged at the southern end of the Dead Sea (e.g. Epstein, 1977). Another source of saltier and warmer waters could be subsurface hot springs described by Niemi and Ben-Avraham (1997). The third possible explanation for the bottom temperature and salinity maxima is slope convection of warm saline brines from the shallow edges of the Dead Sea. Such slope convection was noticed by Dr. Stiller from the Weizmann Institute of Science during her tracer studies in the Dead Sea (personal communication). All these hypotheses have

\section{Density anomaly $\left[\mathrm{kg} / \mathrm{m}^{3}\right]$}

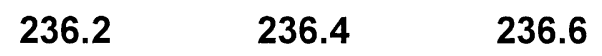

Fig. 9. Vertical distribution of temperature and quasi-salinity in the bottom layer of the Dead Sea (at EG320) during summer 1999 ( $\triangle-$ March; - - June; •-July; $\bullet-$ September).

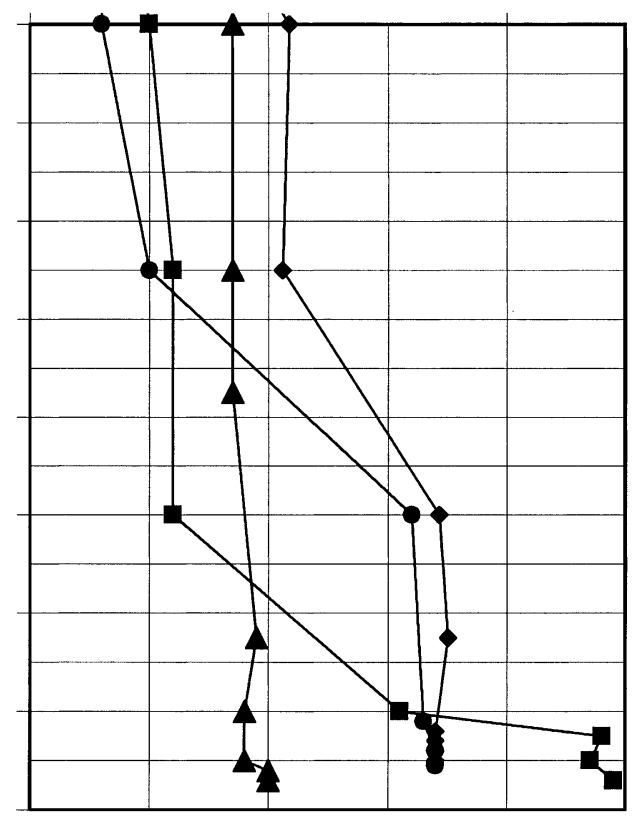




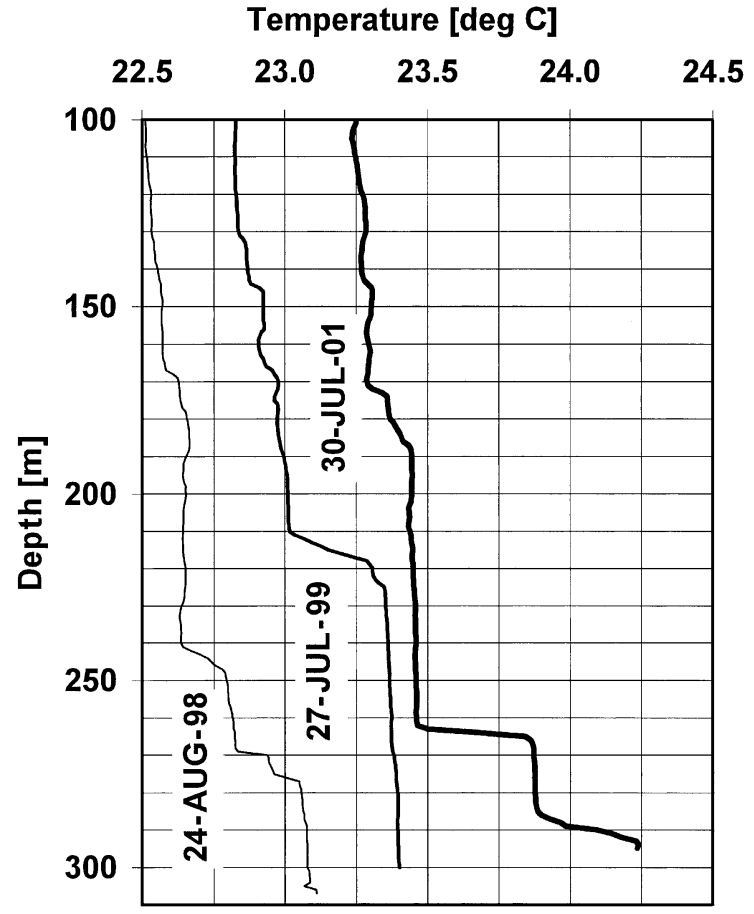

Fig. 10. Detailed profiles of temperature in bottom layer (at EG320) during holomictic summers demonstrating step-like water structure.

yet to be tested, perhaps via detailed water structure analysis.

\section{Summary and conclusions}

The hydrological regime of the Dead Sea has changed twice during the last 10 years of the 20th century. The first change occurred after the very rainy winter of 1991-1992. Enormous inflow of fresh water into the Dead Sea formed a relatively low salinity stable upper layer and the previous holomictic regime switched to a meromictic one. During the following years, the negative fresh water balance induced the monotonic wear of the relatively fresher upper layer up to the winter of 1995-1996. This winter convection mixed the entire Dead Sea and the meromictic period switched again to a holomictic one.

The stability of the water column has been shown to be a reliable parameter, which enables us to determine the switches between a meromictic and a holomictic regime.

During the 1992-1995 meromictic period, the hydrological regime of the Dead Sea was characterized by long-term trends. Thus:

(a) The depth of the seasonal thermocline in the summer increased from $12-15 \mathrm{~m}$ in the summer of 1993 to $25-30 \mathrm{~m}$ in the summer of 1995.

(b) The quasi-salinity of the upper layer increased rapidly by about $16-18 \mathrm{~kg} / \mathrm{m}^{3} /$ year.

(c) The quasi-salinity of the deep water decreased slowly by about $0.08-0.10 \mathrm{~kg} / \mathrm{m}^{3} /$ year.

(d) The winter minimal temperature of the upper layer increased rapidly by about $2{ }^{\circ} \mathrm{C} /$ year.

During the present holomictic period, 1996-2000, the hydrological regime of the Dead Sea is also characterized by long-term trends. Thus:

(a) The quasi-salinity of the entire Dead Sea increases by about $0.5 \mathrm{~kg} / \mathrm{m}^{3} /$ year, with practically no decrease during the winters.

(b) The temperature of the deep water mass increased by about $0.25{ }^{\circ} \mathrm{C} /$ year.

(c) Each year, the winter convective ventilation begins by about a week earlier. Thus, time period during which the waters of the sea are ventilated becomes longer year by year.

\section{Acknowledgements}

The authors are grateful to Captain Moti Gonen and his crew on the R/V Tiulit and R/V Eshet Lot and to the IOLR technical staff, Y. Ben-Kiki, J. Bishop, G. Brokman, J. Mouwes, D. Ramot, Y. Tsehtik, for their help in acquiring the measurements. The Dead Sea level data was kindly provided by the Israel Hydrological Service. We are also indebted to Dr. D.A. Anati who took the trouble to read the manuscript very carefully and suggested many detailed observations. We are also grateful to our referees-Prof. E. Tziperman and an anonymous one, who corrected and improved our paper significantly. This investigation was funded by the Israel Ministry of Energy and Infrastructure. 


\section{References}

Anati, D.A., 1993. How much salt precipitates from the brines of a hypersaline lake? The Dead Sea as a case study. Geochimica et Cosmochimica Acta 57, 2191-2196.

Anati, D.A., 1997. The hydrography of a hypersaline lake. In: Niemi, T.M., Ben-Avraham, Z., Gat, J.R. (Eds.), The Dead Sea: the Lake and its Setting. Oxford Univ. Press, Oxford, pp. 89-103.

Anati, D.A., 1999. The salinity of hypersaline brines: concepts and misconceptions. International Journal of Salt Research 8, 1-16.

Anati, D.A., Shasha, S., 1989. Dead Sea surface-level changes. Israel Journal of Earth Sciences 38, 29-32.

Anati, D.A., Stiller, M., Shasha, S., Gat, J.R., 1987. Changes in the thermo-haline structure of the Dead Sea: 1979-1984. Earth and Planetary Science Letters 57, 2191-2196.

Anati, D.A., Gavrieli, I., Oren, A., 1995. The residual effect of the 1991-93 rainy winters on the Dead Sea stratification. Israel Journal of Earth Sciences 44, 63-70.

Arad, Y., Beyth, M., Bartov, Y., Gavrieli, I., 1998. The Dead Sea and its surroundings, geological and limnological research bibliography. Geological Survey of Israel, Report GSI/2/98, 277 pp.

Beyth, M., Gavrieli, I., Anati, D., Katz, O., 1993. Effects of the December 1991-May 1992 floods on the Dead Sea vertical structure. Israel Journal of Earth Sciences 41, 45-48.

Epstein, J.A., 1977. The recovery of potash from the Dead Sea. Chemistry and Industry 14, 572-576.

Gavrieli, I., 1997. Halite deposition from the Dead Sea: $1960-$ 1993. In: Niemi, T.M., Ben-Avraham, Z., Gat, J.R. (Eds.), The Dead Sea: the Lake and Its Setting. Oxford Univ. Press, Oxford, pp. $161-170$.

Gertman, I.F., Golubeva, Z.A., 1988. Autumn-winter mixing as a factor that defines the water structure of the active layer of the Black Sea. Proceedings of the State Oceanographical Institute 189 , pp. 26-38 (in Russian).

Gertman, I., Ivanov, V.A., Lubartseva, S.P., Michailova, E.N., Shapiro, N.B., 2002. A model of the Dead Sea. Imitation of variability of water thermohaline structure during 1992-2000. Marine Hydrophysical Journal (in Russian), in press.

Hecht, A., Bishop, J., Brokman, G., 1992. The investigation of airsea interaction processes on the Dead Sea: IOLR report No. H14/92, 24 pp.
Hutchinson, G.E., 1957. A Treatise on Limnology. Wiley, New York, $1015 \mathrm{pp}$.

Klein, C., 1960. On the fluctuation of the level of the Dead Sea. Bulletin of the Research Council of Israel 9G, 170-172.

Klein, C., 1981. The influence of rainfall over the catchment area on the fluctuations of the level of the Dead Sea since the 12th century. Israel Meteorological Research Papers 3, 29-58.

Klein, C., 1982. Morphological evidence of lake level changes, western shore of the Dead Sea. Israel Journal of Earth Sciences $31,67-94$.

Klein, M., 1990. Dead Sea level changes. Israel Journal of Earth Sciences 39, 49-50.

Krumgalz, B.S., Hecht, A., Starinsky, A., Katz, A., 2000. Thermodynamic constraints on Dead Sea evaporation: how much can the Dead Sea evaporate? Chemical Geology 165, 1-11.

Neev, D., Emery, K.O., 1967. The Dead Sea. Depositional processes and environments of evaporites. Geological Survey of Israel, Bulletin 41, 147 pp.

Neev, D., Hall, J.K., 1979. Geophysical investigations in the Dead Sea. Sedimentary Geology 23, 209-238.

Niemi, T.M., Ben-Avraham, Z., 1997. Active tectonics in the Dead Sea Basin. In: Niemi, T.M., Ben-Avraham, Z., Gat, J.R. (Eds.), The Dead Sea: the Lake and its Setting. Oxford Univ. Press, Oxford, pp. 73-86.

Salameh, E., Khawaj, M., 1984. The Mediterranean-Dead Sea canal and its environmental impacts, Univ. of Jordan, Aman, Water Research and Study Center, Newsletter No. 2, 36 pp.

Steinhorn, I., 1981. A hydrographical and physical study of the Dead Sea during the destruction of its long-term meromictic stratification. PhD Thesis, Weizmann Institute, Israel, $323 \mathrm{pp}$.

Steinhorn, I., 1985. The disappearance of the long term meromictic stratification of the Dead Sea. Limnology and Oceanography 30, 451-472.

Steinhorn, I., Assaf, G., 1980. The physical structure of the Dead Sea water column, 1975-1977. In: Nissenbaum, A. (Ed.), Hypersaline Brines and Evaporitic Environments. Elsevier, Amsterdam, pp. $155-166$.

Steinhorn, I., Gat, J.R., 1983. The Dead Sea. Scientific American 249 (ý4), 102-109.

Yechieli, Y., Gavrieli, I., Berkowitz, B., Ronen, D., 1998. Will the Dead Sea die? Geology 26, 755-758. 